\title{
Biochar as adsorbent in purification of clear-cut forest runoff water: adsorption rate and adsorption capacity
}

\author{
Taija Saarela $^{1} \mathbb{D} \cdot$ Elham Kakaei Lafdani ${ }^{2} \cdot$ Ari Laurén $^{2} \cdot$ Jukka Pumpanen $^{1} \cdot$ Marjo Palviainen $^{3}$
}

Received: 13 December 2019 / Accepted: 6 April 2020 / Published online: 5 May 2020

(c) The Author(s) 2020

\begin{abstract}
Forest management practices in boreal peatlands increase nutrient export and suspended solids to watercourses calling for development of new water protection methods. One potential solution could be adsorption-based purification of runoff water using biochar. The aim of this study was to determine the adsorption rate and capacity for Norway spruce and silver birch biochars to design a biochar-filled reactor for a ditch drain. In a 10-day laboratory experiment, biochar was stirred with runoff water from a clear-cut peatland forest, and changes in water $\mathrm{pH}$, total nitrogen, nitrate nitrogen, ammonium nitrogen, phosphorus, and total organic carbon concentrations were measured. Based on the concentration changes, adsorption was quantified and adsorption model containing the adsorption rate and capacity was fitted to the data. Our results indicate that biochar effectively adsorbs both inorganic and organic nitrogen from runoff water. Birch biochar had higher adsorption capacity of nitrogen than spruce biochar. This study demonstrates that the adsorption of nitrogen compounds onto biochar surfaces increases with increasing initial concentrations. Thus, aquatic ecosystems exposed to high nutrient loads from fertile peatlands would particularly benefit from biochar-based water purification.
\end{abstract}

Keywords Adsorption $\cdot$ Ammonium $\cdot$ Biochar $\cdot$ Nitrate $\cdot$ Nutrients $\cdot$ Total nitrogen $\cdot$ Water quality

\section{Introduction}

Clear-cutting and ditch network maintenance (ditch cleaning) in drained forested peatlands markedly increase export of nutrients and suspended solids to watercourses (Joensuu et al. 2002; Nieminen 2004; Kaila et al. 2015; Nieminen et al. 2017a). Recent studies also indicate that old drained peatland forests may cause a longer term and much higher nutrient load than previously understood (Nieminen et al. 2017b). It is very likely that climate change will further

Electronic supplementary material The online version of this article (https://doi.org/10.1007/s42773-020-00049-z) contains supplementary material, which is available to authorized users.

Taija Saarela

taija.saarela@uef.fi

1 Department of Environmental and Biological Sciences, University of Eastern Finland, Yliopistonranta 1 E, FI-70210 Kuopio, Finland

2 School of Forest Sciences, University of Eastern Finland, Yliopistokatu 7, FI-80101 Joensuu, Finland

3 Department of Forest Sciences, University of Helsinki, Latokartanonkaari 7, FI-00014 Helsinki, Finland escalate the problem by enhancing peat decomposition and nutrient release (Nieminen et al. 2017b). While current water protection methods such as sedimentation pits, sedimentation ponds, and peatland buffer areas can reduce the export of suspended solids, these methods are rather ineffective in reducing dissolved nutrient load (Joensuu et al. 2002; Liljaniemi et al. 2003; Nieminen et al. 2005). This calls for new methods in water protection. One solution could be adsorption-based active water purification using biocharfilled reactors in ditch drains.

Adsorption process, with activated carbon as adsorbent, is widely used in water purification in chemical engineering. The characteristics of activated carbon are well studied; the adsorption efficiency is based on the exceptionally high specific surface area and porosity. Similarly to activated carbon, biochar is a side product of pyrolysis i.e. heating organic material such as wood, straw, manure, or industrial waste (paper sludge and biosolids) under low oxygen supply (Lehmann and Joseph 2015). Pyrolysis produces energy in the form of biogas and bio-oil, and the remaining carbon-rich solid material is called biochar. Characteristics of biochar resemble those of activated carbon; it has porous structure, large specific surface area and high cation and 
anion exchange capacity, and it is thus capable of adsorbing nutrients and other dissolved compounds from water (Mohan et al. 2014; Tan et al. 2015; Yin et al. 2017). In some studies, the adsorption capacity of biochar has been even better than in activated carbon (Berger 2012; Inyang and Dickenson 2015; Dalahmeh 2016). Biochar has so far mainly been used as a soil amendment, but as a good adsorbent, it may provide a lower cost alternative to activated carbon in wastewater treatment (Foereid 2015; Gwenzi et al. 2016). Recently, adsorption of biochar has been utilized for inorganic nitrogen $(\mathrm{N})$ and phosphorus $(\mathrm{P})$ removal from dairy effluent, piggery slurry, wastewater, and urban runoff water (e.g. Zhang et al. 2012; Hollister et al. 2013; Sarkhot et al. 2013; Zhang et al. 2014; Kizito et al. 2015; Wang et al. 2015; Takaya et al. 2016). However, only very few attempts have been made to use biochar for nutrient reclamation from forest runoff water (e.g. Lafdani et al. 2020) so far.

To design a biochar reactor for water purification, it is necessary $t$ know the adsorption rate and adsorption capacity of the biochar for the prevailing substances in the water. Previous laboratory experiments indicate that biochar can adsorb compounds from water; however, these experiments have typically been done for single compounds, whereas simultaneous adsorption of several compounds from natural waters has not been studied before. As multiple compounds compete simultaneously for the adsorption places in the adsorption process (Palviainen et al. 2018), all dissolved compounds in the water can affect the performance of biochar in nutrient reclamation. The chemical composition and nutrient concentrations of peatland forest runoff water differ significantly from agricultural or urban runoff waters (Oliveira et al. 2018). Therefore, the studies reporting biochar utilization in contaminant removal from agricultural and urban waters cannot be directly applied for forested peatlands.

This study was part of a research project aimed at developing biochar-based water protection tools for forestry. Different scales, such as a small-scale laboratory experiment, meso-scale laboratory experiment, and a full-field scale study (biochar reactors installed into ditch drains), were applied during the project. The aim of this study was to determine the adsorption rate and adsorption capacity for two wood biochars (Norway spruce and silver birch) representing the most common raw biochar materials in Finland. We carried out a 10-day laboratory experiment where biochar was stirred with runoff water from a clearcut peatland area at constant temperature. Changes in water $\mathrm{pH}$, total nitrogen $(\mathrm{TN})$, nitrate nitrogen $\left(\mathrm{NO}_{3}{ }^{-} \mathrm{N}\right)$, ammonium nitrogen $\left(\mathrm{NH}_{4}{ }^{+}-\mathrm{N}\right)$, phosphorus $(\mathrm{P})$ and total organic carbon (TOC) concentrations were measured throughout the experiment. Adsorption was quantified based on the concentration changes, and adsorption model containing the adsorption rate and adsorption capacity was fitted to the data. Implications of the results on the reactor design for forested peatland water protection purposes were discussed.

\section{Materials and methods}

\subsection{Study site}

Study site was located in Heinävesi, Eastern Finland $\left(62^{\circ}\right.$ $29^{\prime} 56.0^{\prime \prime} \mathrm{N}, 28^{\circ} 35^{\prime} 56.0^{\prime \prime}$ E, Fig. 1). The mean annual temperature in the area is $3.6^{\circ} \mathrm{C}$ and the mean annual precipitation is $638 \mathrm{~mm}$ (Pirinen et al. 2012). The site is a drained fertile spruce fen (Päivänen and Hånell 2012) that was clear-cut in August 2018. In the clear-cut, a total of $319 \mathrm{~m}^{3}\left(124 \mathrm{~m}^{3} \mathrm{ha}^{-1}\right)$ Norway spruce (Picea abies Karst.) and $239 \mathrm{~m}^{3}\left(93 \mathrm{~m}^{3} \mathrm{ha}^{-1}\right)$ silver birch (Betula pendula Roth.) were harvested. Total catchment area was $31.72 \mathrm{ha}$, and the size of the clear-cut area was 2.57 ha. The depth of the peat layer was $0.5-0.7 \mathrm{~m}$ and it was underlain by clay.

Water for the adsorption experiment was collected from a ditch that drains the clear-cut area in two sampling occasions dated in October and November 2018. The initial nutrient concentrations of water were higher in November $\left(1.4 \pm 0.05 \mathrm{mg} \mathrm{l}^{-1} \mathrm{TN}, 0.6 \pm 0.09 \mathrm{mg} \mathrm{l}^{-1} \mathrm{NO}_{3}{ }^{-}-\mathrm{N}\right.$, $0.1 \pm 0.02 \mathrm{mg} \mathrm{l}^{-1} \mathrm{NH}_{4}{ }^{-}-\mathrm{N}$ and $28 \pm 0.01 \mathrm{mg} \mathrm{l}^{-1}$ TOC) than in October $\left(0.9 \pm 0.03 \mathrm{mg} \mathrm{l}^{-1} \mathrm{TN}, 0.2 \pm 0.01 \mathrm{mg} \mathrm{l}^{-1} \mathrm{NO}_{3}{ }^{-} \mathrm{-N}\right.$, $0.05 \pm 0.03 \mathrm{mg} \mathrm{l}^{-1} \mathrm{NH}_{4}{ }^{+}-\mathrm{N}$ and $25 \pm 0.2 \mathrm{mg} \mathrm{l}^{-1}$ TOC). The runoff from the clear-cut site flows into an oligo-mesotrophic, clear-water Lake Kermajärvi in the Vuoksi main catchment area. Nutrient exports following clear-cut from fertile peatland sites may jeopardize the good ecological status of oligo-mesotrophic clear-water lakes. Active water purification methods can be particularly suitable for sites where balancing between high economic income and high environmental risk is required.

\subsection{Experimental design}

We used two different commercial biochar types (Norway spruce and silver birch, Table 1) produced by slow pyrolysis at $600{ }^{\circ} \mathrm{C}$ (Carbofex Ltd., Tampere, Finland). In recent studies, high biomass pyrolysis temperature $\left(600{ }^{\circ} \mathrm{C}\right)$ has been shown to increase the adsorption capacity (e.g. Yao et al. 2012). To determine the effect of biochar particle size and dose on the adsorption rate and capacity, we selected two different particle sizes (fine $<4 \mathrm{~mm}$ and coarse 4-6 mm) and two different doses ( $3 \mathrm{~g}$ and $12 \mathrm{~g}$ ). Largitte and Pasquier (2016) identified three steps in the adsorption process: (1) the external mass transfer of the adsorbate from the bulk solution to the external surface of the adsorbent, (2) the internal diffusion of the adsorbate to the sorption sites and (3) the actual sorption. Particle size affects especially the first two steps. All treatments were conducted in four 
Fig. 1 Study site in Heinävesi, Eastern Finland (PaITulispatial data for research and teaching; available at https:// avaa.tdata.fi/en_US/web/paituli/ latauspalvelu)

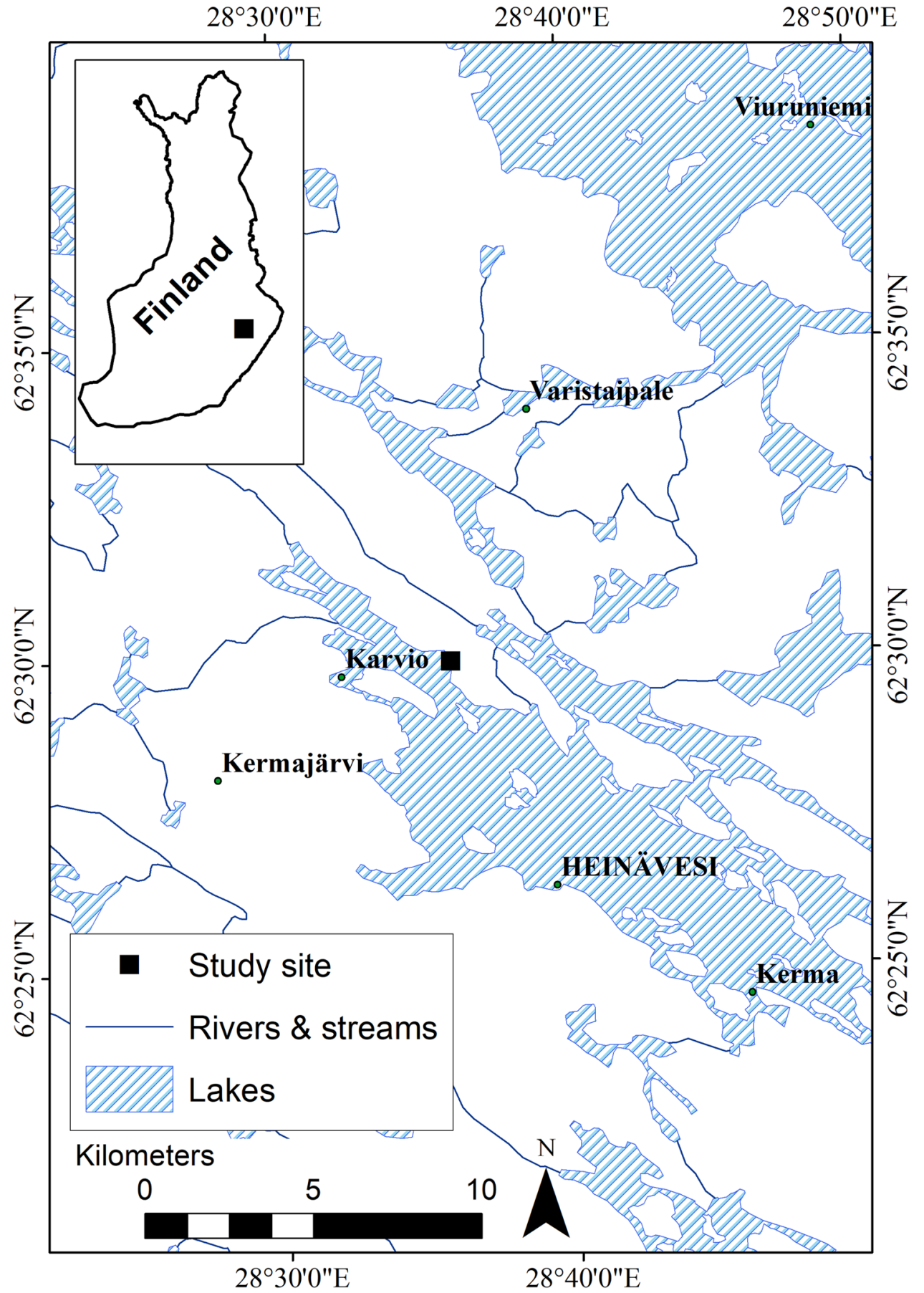

replicates. The runoff water collected in October was used for replicates 1 and 2, and runoff water collected in November was used for replicates 3 and 4. Before the experiment, water temperature was allowed to stabilize to room temperature $\left(+21{ }^{\circ} \mathrm{C}\right)$ which fit within the temperature range in field conditions (from $-25{ }^{\circ} \mathrm{C}$ to $+25^{\circ} \mathrm{C}$ ). Temperature was standardized among the replicates and kept constant throughout the experiment, because temperature is known to affect the adsorption process (Mizuta et al. 2004). We added biochar into $3000 \mathrm{ml}$ glass jars and four glass jars remained blank controls without biochar. Thereafter, $2500 \mathrm{ml}$ of water from the field site was added to the jars, and $60 \mathrm{ml}$ of water was taken to measure the initial element concentration in each jar. Jars were covered with aluminum foil and placed on a platform shaker (New Brunswick ${ }^{\mathrm{TM}}$ Innova $^{\circledR} 2300$, Eppendorf Nordic A/S, Denmark). Glass jars were shaken at $105 \mathrm{rpm}$ for 10 days, and $60 \mathrm{ml}$ water sample was taken from each jar at following points of time: 1, 2.33, 5.5, 25, $28,46,49,70,145,169,196$, and $215 \mathrm{~h}$ from the beginning of the experiment. The samples were filtered through 
Table 1 Characteristics of the spruce and birch biochars

\begin{tabular}{lll}
\hline & Norway spruce & Silver birch \\
\hline $\begin{array}{l}\text { Pyrolysis temperature }\left({ }^{\circ} \mathrm{C}\right) \\
\mathrm{pH}(1: 2.5 \mathrm{v}: \mathrm{v} \text { biochar/water solu- }\end{array}$ & $600{ }^{\circ} \mathrm{C}$ & $600{ }^{\circ} \mathrm{C}$ \\
$\quad$ tion $)$ & $9.25(0.01)$ & $9.75(0.02)$ \\
$\begin{array}{l}\text { Electric conductivity }\left(\mu \mathrm{S} \mathrm{cm}^{-1}\right) \\
\quad(1: 2.5 \text { v:v biochar/water solution })\end{array}$ & $221(15)$ & $163(3)$ \\
Specific surface area $\left(\mathrm{m}^{2} \mathrm{~g}^{-1}\right)$ & 320 & 260 \\
Dry matter $(\%)\left(105{ }^{\circ} \mathrm{C}, 48 \mathrm{~h}\right)$ & $72.69 \%(2.74)$ & $81.03 \%(1.86)$ \\
$\mathrm{C}(\%)$ & $79.07(0.83)$ & $80.00(0.05)$ \\
$\mathrm{N}(\%)$ & $1.19(0.09)$ & $1.39(0.15)$ \\
$\mathrm{C}: \mathrm{N}$ ratio & $66.93(5.51)$ & $58.20(6.38)$ \\
\hline
\end{tabular}

Values are mean $( \pm \mathrm{SD})$

Filtration Assembly with Whatman GF/F Glass Microfiber Filters (pore size $0.7 \mu \mathrm{m}$, GE Healthcare Bio-Sciences, Marlborough, MA, USA). The samples were stored at $+4{ }^{\circ} \mathrm{C}$ until further analysis.

\subsection{Measurements and analyses}

Carbon (C) and nitrogen (N) concentration change was measured to determine the adsorption of compounds onto the biochar surfaces (Eq. 1).

$Q_{t_{-} i}=\frac{\left(C_{\mathrm{ini} \_} i V_{\mathrm{ini}}-C_{t_{-} i} V_{t}\right)-\sum_{k=\text { ini }}^{t}\left(C_{k_{-} i} V_{\text {sample }}\right)}{m_{\text {biochar }}}$,

where $Q_{t_{-} i}$ is the cumulative adsorption of substance $i$ ( $\mathrm{mg} \mathrm{g}^{-1}$ biochar), $C_{\text {ini }_{i} i}$ is the initial concentration of substance $i\left(\mathrm{mg} \mathrm{l}^{-1}\right), V_{\mathrm{ini}}$ is the water initial volume (1), $C_{t_{-i}}$ is the concentration of substance $i$ in time $t\left(\mathrm{mg} \mathrm{l}^{-1}\right), V_{t}$ is water volume at time $t, C_{k i}$ is the concentration of substance $i$ in previous sampling occasion at time $k, V_{\text {sample }}$ is the volume of water sample in each sampling occasion $(60 \mathrm{ml})$, and $m_{\text {biochar }}$ is the dry mass of biochar in the jar.

Electrical conductivity (EC) and $\mathrm{pH}$ of water and biochars (on a 1:2.5 v:v biochar/water solution) were measured from each sample using WTW $\mathrm{pH} /$ cond 340i and WTW pH 340 m (WTW GmbH, Weilheim, Germany), respectively. Total organic carbon (TOC) and total nitrogen (TN) concentrations were determined with Multi N/C ${ }^{\circledR}$ 2100 (Analytik Jena AG, Jena, Germany). The concentrations of nitrate $\left(\mathrm{NO}_{3}{ }^{-}\right)+$nitrite $\left(\mathrm{NO}_{2}^{-}\right)$nitrogen (hereafter referred to as $\left.\mathrm{NO}_{3}{ }^{-}-\mathrm{N}\right)$ and ammonium nitrogen $\left(\mathrm{NH}_{4}{ }^{+}-\mathrm{N}\right)$ were determined colorimetrically applying the methods by Miranda et al. (2001) and Fawcett and Scott (1960), respectively. The concentrations of phosphorus $(\mathrm{P})$ were determined by ICP atomic emission spectrophotometer (ARL 3580 OES, Fison Instruments, Valencia, USA). The $\mathrm{C}$ and $\mathrm{N}$ concentrations of biochars were analyzed with an elemental analyzer (Vario Max CN elemental analyser, Elementar Analysensysteme GmbH, Germany).

\subsection{Data analyses}

Adsorption rate and capacity were determined by fitting commonly used integral form of pseudo-second-order adsorption model to the data (Largitte and Pasquier 2016, Eq. 2)

$Q_{i}=\left(\frac{k_{\mathrm{ad}_{i} i} i Q_{Q_{\max \_} i} t}{1+k_{\mathrm{ad}_{\_} i} Q_{\max _{-} i} t}\right)$,

where $Q_{i}$ is cumulative adsorption of substance $i(\mathrm{TN}$, $\mathrm{NH}_{4}{ }^{+}-\mathrm{N}, \mathrm{NO}_{3}{ }^{-}-\mathrm{N}$ and TOC, $\mathrm{mg} \mathrm{g}^{-1}$ biochar) at time $t(\mathrm{~h})$, $k_{\text {ad } \_i}$ is adsorption rate $\left(\mathrm{g} \mathrm{mg}^{-1} \mathrm{~h}^{-1}\right)$, and $Q_{\text {max }_{-} i}\left(\mathrm{mg} \mathrm{g}^{-1}\right)$ is adsorption capacity for substance $i$.

The effect of treatments (biochar type, particle size and dose) on $k_{\text {ad }}$ and $Q_{\max }$ were analyzed using nonlinear mixed-effect models (Online Resource 1). At first, a basic model, where all treatments for compound $i$ were included to the analysis was calculated, and the performance of the model expressed as information criteria (AIC, BIC, -log likelihood) were recorded. Then different treatments were addressed as fixed effects of $k_{\text {ad }}$ and/or $Q_{\max }$ in the analysis and the model performance was evaluated against the previous step model. Replicates were considered as random effects in the model.

Our analysis revealed that $k_{\text {ad }}$ and $Q_{\max }$ were different for experiments done in October and November, indicating that the initial concentration affects the adsorption. This allowed us to use the initial concentration as an extra treatment in the analysis. Because the solution of nonlinear mixedeffect model is iterative, the model does not converge if the variance structure greatly deviates between the treatments. Therefore, we did separate analyses for different biochar doses and initial concentrations.

\section{Results}

\section{1 $\mathrm{pH}$ and EC}

Biochar increased water $\mathrm{pH}$ throughout the experiment (Fig. $\mathrm{S} 1)$. Increases in $\mathrm{pH}$ were higher among treatments with $12 \mathrm{~g}$ dose of biochar (increase $16 \%$ from the initial) compared to $3 \mathrm{~g}$ dose (increase 12\%). Electrical conductivity (EC) increased in all biochar treatments by $20 \%$ (Fig. S2), and the changes were similar in both biochar doses. Water $\mathrm{pH}$ and EC did not differ between birch and spruce biochar treatments. 


\subsection{The concentration changes and adsorption of TN}

Biochar decreased TN concentrations in water (Fig. 2). The largest decrease in $\mathrm{TN}$ was observed during the first $70 \mathrm{~h}$ of the experiment. The adsorption of TN was detected in all biochar treatments (Fig. 3). The differences among the treatments were the most evident in $Q_{\max }$ (Table 2). Birch biochar has predominantly higher $Q_{\max }$ than spruce biochar (Fig. 3). The adsorption process was more consistent in higher biochar dose and higher concentration, which can be seen from Fig. 3 and residual variance in Table 2. Particle size did not have an effect on $k_{\mathrm{ad}}$, while $Q_{\max }$ increased with decreasing particle size. Experiment revealed that adsorption increases with increasing initial concentration. $Q_{\max }$ was in most cases about two times higher for initial concentration $1.4 \mathrm{mg} \mathrm{l}^{-1}$ compared to $0.9 \mathrm{mg} \mathrm{l}^{-1}$.

\subsection{The concentration changes and adsorption of inorganic $\mathbf{N}$}

The $\mathrm{NO}_{3}{ }^{-}$-N concentrations decreased in all biochar-treated samples throughout the experiment (Fig. 4). The steepest decline in $\mathrm{NO}_{3}{ }^{-}-\mathrm{N}$ was detected in the samples with $12 \mathrm{~g}$ of birch biochar (Fig. 4a, c). Furthermore, $Q_{\max }$ for $\mathrm{NO}_{3}{ }^{-}-\mathrm{N}$ was the highest in birch biochar treated samples and generally increased with increasing initial concentration (Fig. 5; Table 3). The biochar particle size did not have a clear effect on $\mathrm{NO}_{3}{ }^{-}-\mathrm{N}$ adsorption.
$\mathrm{NH}_{4}{ }^{+}-\mathrm{N}$ concentrations were low and decreased rapidly in all biochar treatments below the detection limit $\left(0.02 \mathrm{mg}^{-1}\right.$; Fig. 6). The decrease in $\mathrm{NH}_{4}{ }^{+}-\mathrm{N}$ was more evident in the samples with $12 \mathrm{~g}$ of biochar (Fig. 6a-d). In the situation where the adsorbing compound is depleted from the water, fitting the adsorption model is not meaningful, because then $Q_{\max }$ would not represent the real adsorption capacity of biochar.

\subsection{The concentration changes of TOC and P}

The concentrations of TOC decreased in samples with high initial concentrations $\left(28 \mathrm{mg} \mathrm{l}^{-1}\right)$ during the first 2 days of the experiment (Fig. S3). After 145 h, TOC concentrations did not differ substantially between biochar and control treatments, and there were increases in TOC among all treatments.

The concentrations of $\mathrm{P}$ were below the detection limit $\left(0.025 \mathrm{mg} \mathrm{l}^{-1}\right)$ throughout the experiment, and, therefore, it was not possible to determine the adsorption parameters for P.

\section{Discussion}

Our study indicated that spruce and birch biochar can adsorb both organic and inorganic $\mathrm{N}$. The review study by Yin et al. (2017) about biochar utilization for inorganic $\mathrm{N}$ removal from water showed that biochar can adsorb between
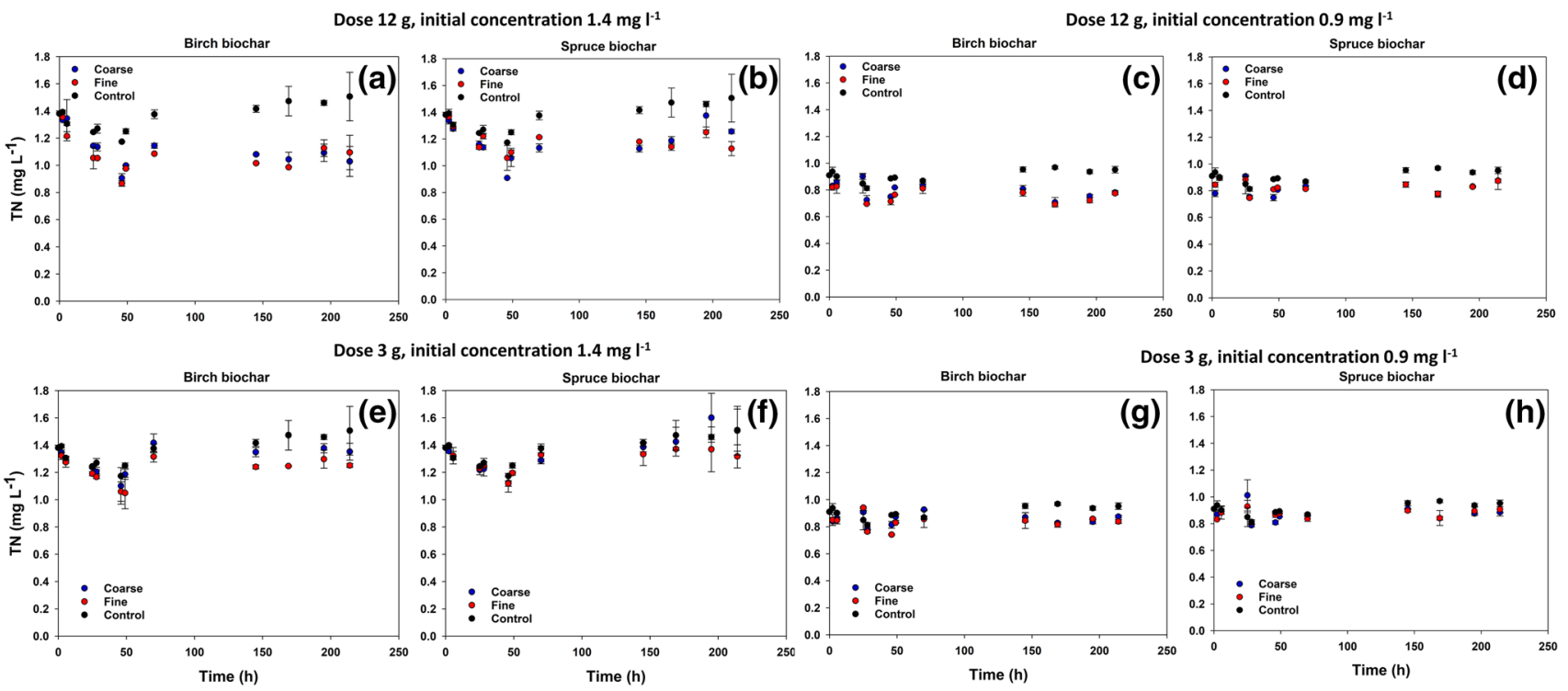

Fig. 2 The effect of biochar on TN concentrations in different treatments: a $12 \mathrm{~g}$ of birch biochar and $\mathbf{b} 12 \mathrm{~g}$ of spruce biochar (initial concentration $1.4 \mathrm{mg} \mathrm{l}^{-1}$ ), c $12 \mathrm{~g}$ of birch biochar and d $12 \mathrm{~g}$ of spruce biochar (initial concentration $0.9 \mathrm{mg} \mathrm{l}^{-1}$ ), e $3 \mathrm{~g}$ of birch biochar and $\mathbf{f} 3 \mathrm{~g}$ of spruce biochar (initial concentration $1.4 \mathrm{mg} \mathrm{l}^{-1}$ ), and g $3 \mathrm{~g}$ of birch biochar and $\mathbf{h} 3 \mathrm{~g}$ of spruce biochar (initial concentration $\left.0.9 \mathrm{mg} \mathrm{l}^{-1}\right)$. Values are mean $\pm \mathrm{SD}$. Blue dots represent coarse particle size $(4-6 \mathrm{~mm})$, red dots represent fine particle size $(<4 \mathrm{~mm})$, and black dots are blank water samples without biochar (colour figure online) 

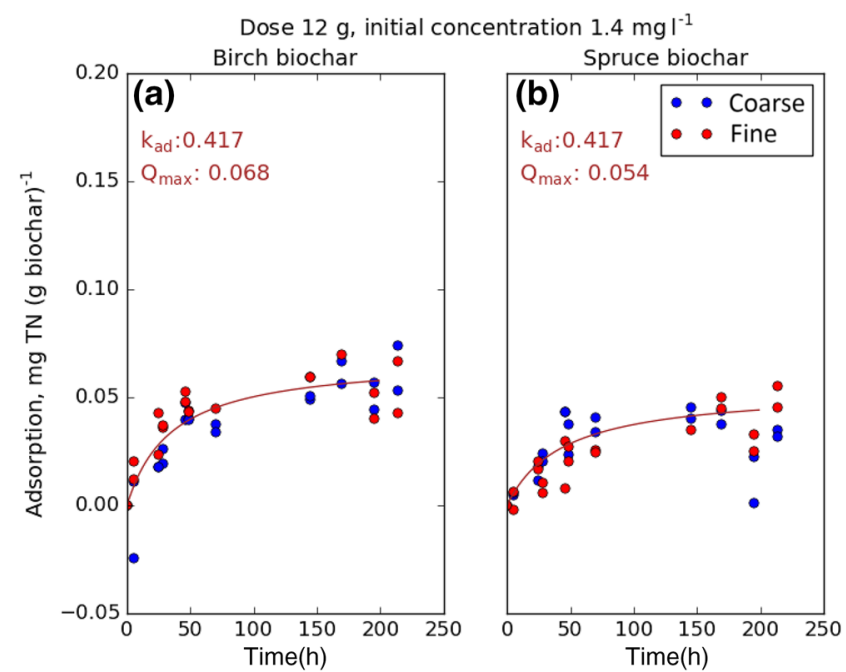

Dose $3 \mathrm{~g}$, initial concentration $1.4 \mathrm{mgl}^{-1}$
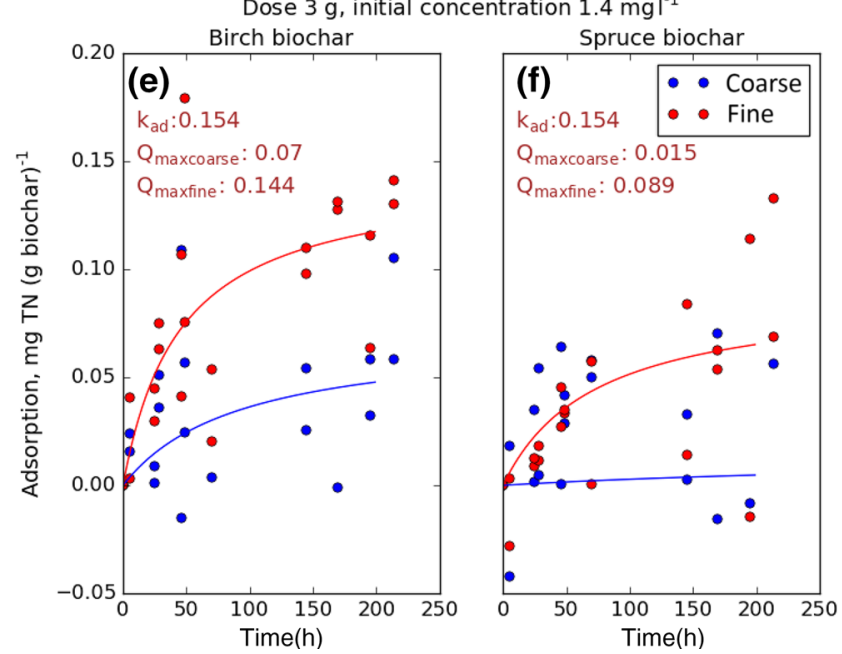

Fig. 3 The adsorption of $\mathrm{TN}$ in different treatments: a $12 \mathrm{~g}$ of birch biochar and b $12 \mathrm{~g}$ of spruce biochar (initial concentration $1.4 \mathrm{mg}^{-1}$ ), c $12 \mathrm{~g}$ of birch biochar and $\mathbf{d ~} 12 \mathrm{~g}$ of spruce biochar (initial concentration $0.9 \mathrm{mg}^{-1}$ ), e $3 \mathrm{~g}$ of birch biochar and $\mathbf{f} 3 \mathrm{~g}$ of spruce biochar (initial concentration $1.4 \mathrm{mg} \mathrm{l}^{-1}$ ), and $\mathbf{g} 3 \mathrm{~g}$ of birch biochar and $\mathbf{h ~} 3 \mathrm{~g}$ of spruce biochar (initial concentration $0.9 \mathrm{mg} \mathrm{l}^{-1}$ ).

0.7 and $140 \mathrm{mg}$ inorganic $\mathrm{N} \mathrm{g}^{-1}$ biochar. Our results were below this range, being maximum at $0.14 \mathrm{mg} \mathrm{g}^{-1}$ biochar for $\mathrm{TN}$, although wood biochars have generally higher $\mathrm{NO}_{3}{ }^{-}-\mathrm{N}$ adsorption capacity than non-wood biochars (Kameyama et al. 2016). The lower adsorption capacity in our study was probably due to the low initial $\mathrm{N}$ concentrations in the water. Our results support the findings of Ahmadvand et al. (2018), showing that with an increase in the initial $\mathrm{N}$ concentration of solution, the adsorption capacity of biochar tends to increase.

The low initial concentrations of $\mathrm{NH}_{4}{ }^{+}-\mathrm{N}\left(<0.1 \mathrm{mg} \mathrm{l}^{-1}\right)$ and $\mathrm{P}\left(<0.025 \mathrm{mg} \mathrm{l}^{-1}\right)$ were also the reason why we could not determine the adsorption parameters for these compounds, but based on the literature, it is known that biochar
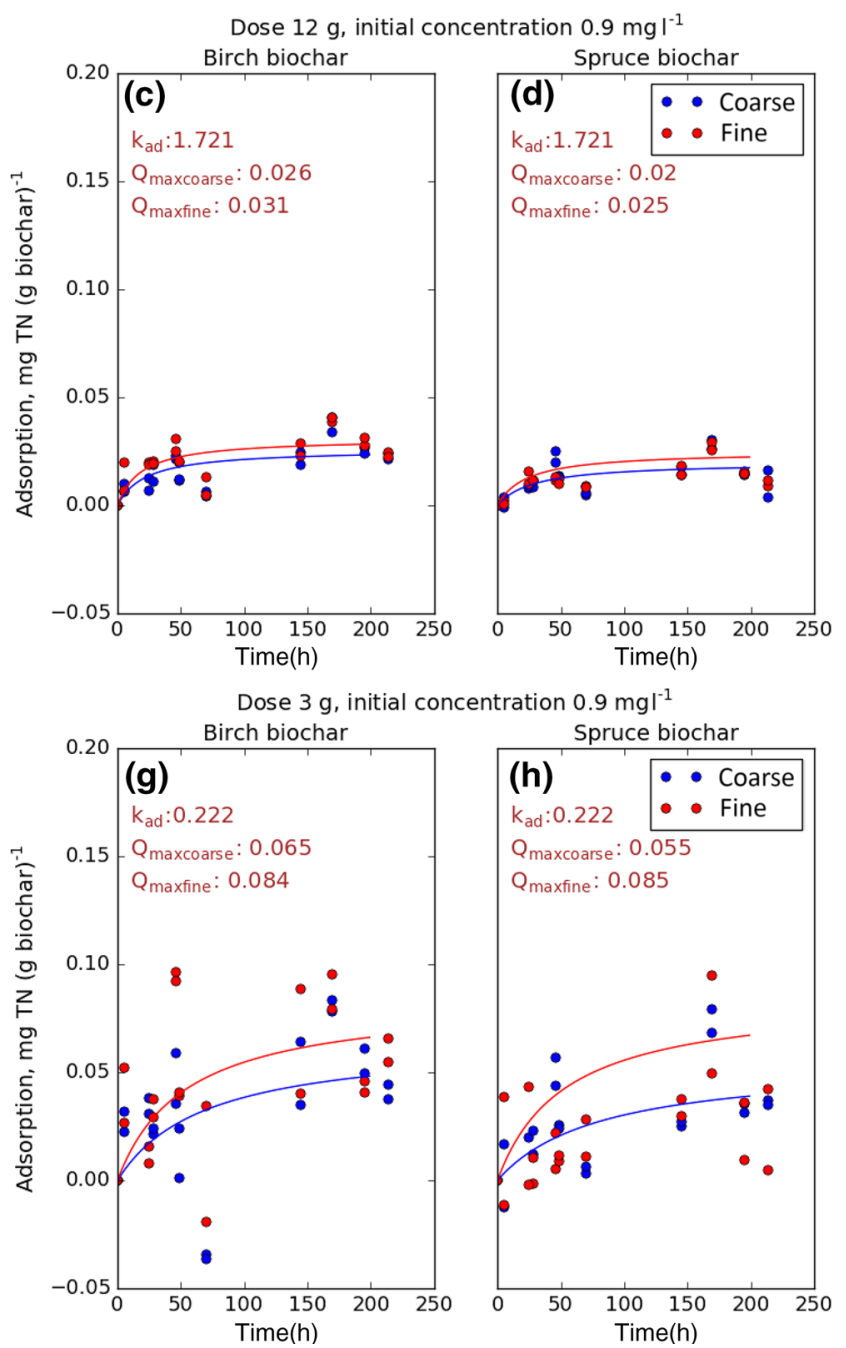

The solid lines represent pseudo-second-order adsorption model (Eq. 1) fitted using non-linear mixed effect model. Parameter values for adsorption rate $\left(k_{\mathrm{ad}}\right)$ and adsorption capacity $\left(Q_{\max }\right)$ are shown in each figure. Blue dots and lines represent coarse particle size $(4-6 \mathrm{~mm})$ and red dots and lines represent fine particle size $(<4 \mathrm{~mm})$ (colour figure online)

is an effective adsorbent also for $\mathrm{NH}_{4}{ }^{+}-\mathrm{N}$ and $\mathrm{P}$ (Yin et al. 2017). However, $\mathrm{NH}_{4}{ }^{+}-\mathrm{N}$ was adsorbed initially until the concentrations decreased below the detection limit (0.02 mg l ${ }^{-1}$; Fig. 6). Small fraction of the $\mathrm{NH}_{4}{ }^{+}-\mathrm{N}$ may have been lost through volatilization (Sha et al. 2019), but the significance of this process is probably negligible because water $\mathrm{NH}_{4}^{+}-\mathrm{N}$ concentrations were low. Even though the surfaces of carbon-based materials are often thought to be negatively charged (Eberhardt et al. 2006; Krishnan and Haridas 2008; Yao et al. 2011), the adsorption of both $\mathrm{NO}_{3}{ }^{-}-\mathrm{N}$ and $\mathrm{NH}_{4}{ }^{+}-\mathrm{N}$ indicates that biochar is capable to adsorb both anions and cations.

Adsorption rates were similar between different biochar treatments (Figs. 3, 5). The largest differences among the 
Table 2 Nonlinear mixed-effect models for $\mathrm{TN}$ in different treatments

\begin{tabular}{|c|c|c|c|c|c|c|c|c|c|}
\hline & Value & $\mathrm{SE}$ & $\mathrm{DF}$ & $p$ value & & Value & SE & DF & $p$ value \\
\hline \multicolumn{5}{|c|}{ Dose $12 \mathrm{~g}$, initial $\mathrm{TN}$ concentration $1.4 \mathrm{mg}^{-1}$} & \multicolumn{5}{|c|}{ Dose $3 \mathrm{~g}$, initial TN concentration $1.4 \mathrm{mg}^{-1}$} \\
\hline$k_{\text {ad }}$ & 0.417 & 0.196 & 76 & 0.037 & $k_{\mathrm{ad}}$ & 0.154 & 0.117 & 75 & 0.192 \\
\hline$Q_{\max }$ birch & 0.068 & 0.008 & 76 & $<0.001$ & $\begin{array}{l}Q_{\max } \text { birch } \\
\text { coarse }\end{array}$ & 0.07 & 0.021 & 75 & 0.001 \\
\hline \multirow[t]{3}{*}{$Q_{\max }$ spruce } & \multirow[t]{3}{*}{-0.013} & \multirow[t]{3}{*}{0.005} & \multirow[t]{3}{*}{76} & \multirow[t]{3}{*}{0.013} & $Q_{\max }$ spruce & -0.055 & 0.031 & 75 & 0.078 \\
\hline & & & & & $Q_{\max }$ fine & 0.074 & 0.02 & 75 & 0.0004 \\
\hline & & & & & $\begin{array}{l}Q_{\max } \\
\text { fine } \times \text { spruce }\end{array}$ & -0.004 & 0.033 & 75 & 0.906 \\
\hline \multicolumn{5}{|c|}{ Dose $12 \mathrm{~g}$, initial TN concentration $0.9 \mathrm{mg} \mathrm{l}^{-1}$} & \multicolumn{5}{|c|}{ Dose $3 \mathrm{~g}$, initial TN concentration $0.9 \mathrm{mg}^{-1}$} \\
\hline$k_{\text {ad }}$ & 1.721 & 0.657 & 75 & 0.011 & $k_{\mathrm{ad}}$ & 0.222 & 0.174 & 76 & 0.207 \\
\hline$Q_{\max }$ birch coarse & 0.026 & 0.002 & 75 & $<0.0001$ & $\begin{array}{l}Q_{\text {max }} \text { birch } \\
\text { coarse }\end{array}$ & 0.065 & 0.016 & 76 & 0.0001 \\
\hline$Q_{\max }$ spruce & -0.006 & 0.002 & 75 & 0.023 & $Q_{\max }$ spruce & -0.01 & 0.012 & 76 & 0.428 \\
\hline$Q_{\max }$ fine & 0.005 & 0.002 & 75 & 0.027 & $Q_{\max }$ fine & 0.019 & 0.012 & 76 & 0.104 \\
\hline$Q_{\max }$ fine $\times$ spruce & -0.006 & 0.003 & 75 & 0.09 & $\begin{array}{l}Q_{\max } \\
\text { fine } \times \text { spruce }\end{array}$ & -0.023 & 0.017 & 76 & 0.186 \\
\hline
\end{tabular}

The uppermost line for $Q_{\max }$ represents the basic level of the adsorption capacity; the other treatment effects and the interaction effects are expressed as a difference with respect to this basic level. Absolute $Q_{\max }$ values are presented in Fig. 3
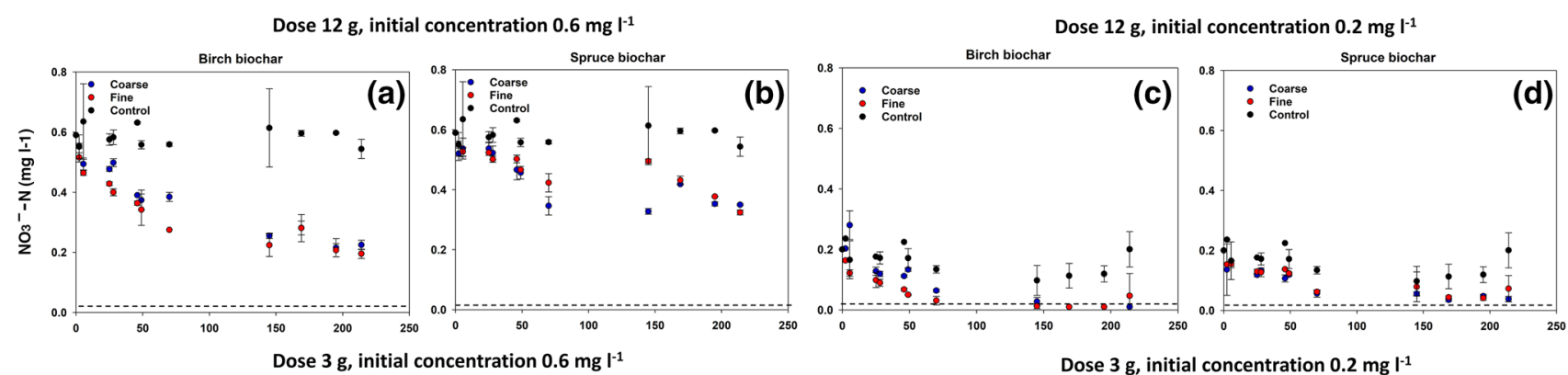
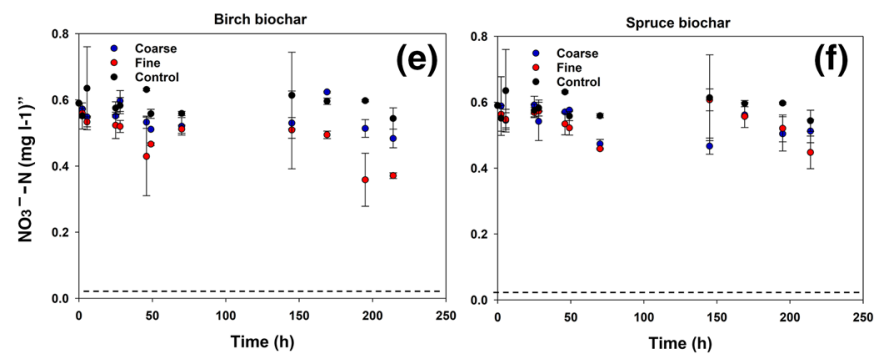

Fig. 4 The effect of biochar on $\mathrm{NO}_{3}{ }^{-} \mathrm{N}$ concentrations in different treatments: a $12 \mathrm{~g}$ of birch biochar and $\mathbf{b} 12 \mathrm{~g}$ of spruce biochar (initial concentration $0.6 \mathrm{mg} \mathrm{l}^{-1}$ ), $\mathbf{c ~} 12 \mathrm{~g}$ of birch biochar and $\mathbf{d ~} 12 \mathrm{~g}$ of spruce biochar (initial concentration $0.2 \mathrm{mg} \mathrm{l}^{-1}$ ), e $3 \mathrm{~g}$ of birch biochar and $\mathbf{f} 3 \mathrm{~g}$ of spruce biochar (initial concentration $0.6 \mathrm{mg}^{-1}$ ), and

treatments can be seen in the adsorption capacity. $Q_{\max }$ decreased with the increasing biochar particle size, which could be due to that the surface area where adsorption can take place is smaller when the particle size increases (Eberhardt and Min 2008). However, despite higher specific surface area of spruce biochar $\left(320 \mathrm{~m}^{2} \mathrm{~g}^{-1}\right)$ compared to birch biochar $\left(260 \mathrm{~m}^{2} \mathrm{~g}^{-1}\right), Q_{\max }$ was higher with birch biochar.

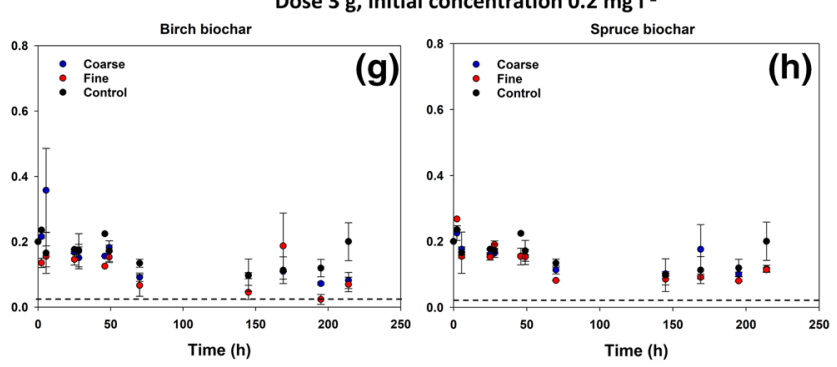

g $3 \mathrm{~g}$ of birch biochar and $\mathbf{h} 3 \mathrm{~g}$ of spruce biochar (initial concentration $0.2 \mathrm{mg} \mathrm{l}^{-1}$ ). Values are mean $\pm \mathrm{SD}$. Dashed lines represent the detection limit $\left(0.02 \mathrm{mg} \mathrm{l}^{-1}\right)$. Blue dots represent coarse particle size (4-6 mm), red dots represent fine particle size $(<4 \mathrm{~mm})$, and black dots are blank water samples without biochar (colour figure online)

While the increase in the biochar surface area may improve $\mathrm{N}$ adsorption (Zhang et al. 2012), the adsorption capacity is not exclusively dependent on the biochar surface area (Zhang et al. 2014; Takaya et al. 2016).

The effect of biochar on water quality was visible in elevated $\mathrm{pH}$ (Fig. S1). Water $\mathrm{pH}$ is an important factor regulating ion exchange capacity and, therefore, $\mathrm{N}$ adsorption 

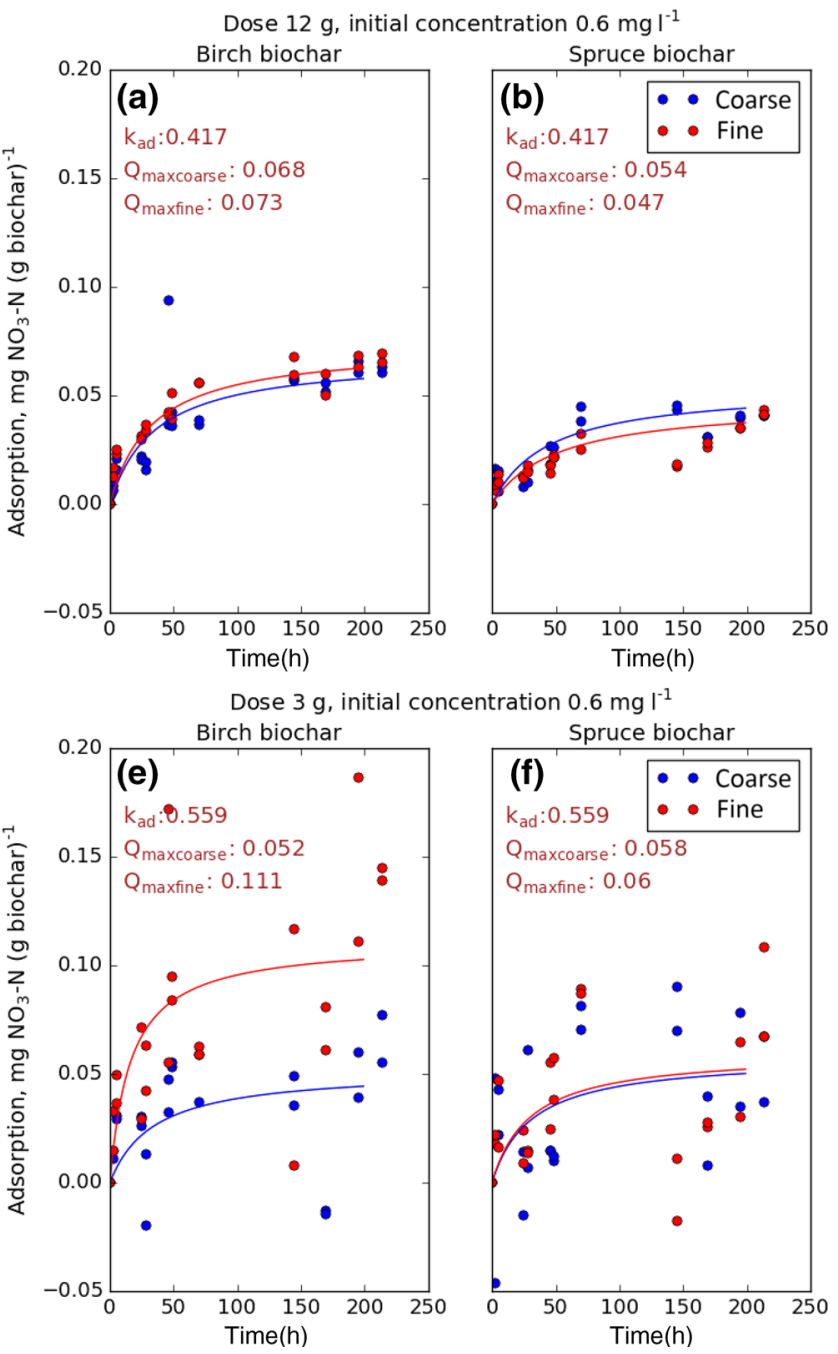

Fig. 5 The adsorption of $\mathrm{NO}_{3}^{-}-\mathrm{N}$ in different treatments: a $12 \mathrm{~g}$ of birch biochar and $\mathbf{b} 12 \mathrm{~g}$ of spruce biochar (initial concentration $\left.0.6 \mathrm{mg} \mathrm{l}^{-1}\right)$, c $12 \mathrm{~g}$ of birch biochar and $\mathbf{d ~} 12 \mathrm{~g}$ of spruce biochar (initial concentration $0.2 \mathrm{mg} \mathrm{l}^{-1}$ ), e $3 \mathrm{~g}$ of birch biochar and $\mathbf{f} 3 \mathrm{~g}$ of spruce biochar (initial concentration $0.6 \mathrm{mg} \mathrm{l}^{-1}$ ), and $\mathbf{g} 3 \mathrm{~g}$ of birch biochar and $\mathbf{h} 3 \mathrm{~g}$ of spruce biochar (initial concentration $0.2 \mathrm{mg} \mathrm{l}^{-1}$ ).

on biochar (Yin et al. 2017). The adsorption capacity of biochar has been shown to increase as the $\mathrm{pH}$ value of the solution increases from 4 to 8 (Yin et al. 2017). The initial $\mathrm{pH}$ in our water samples was moderately acidic (approx. 6), which is typical for waters draining from boreal peatlands (Åström et al. 2001). At low pH values, $\mathrm{H}^{+}$and $\mathrm{NH}_{4}{ }^{+}$can compete for the active sites on the biochar surfaces (Novak et al. 2010), which slows down $\mathrm{N}$ adsorption. On the other hand, $\mathrm{NO}_{3}{ }^{-} \mathrm{N}$ is poorly adsorbed under basic conditions due to the competition between hydroxide ions $\left(\mathrm{OH}^{-}\right)$and $\mathrm{NO}_{3}{ }^{-}$-N ions for the adsorption sites on the biochar surfaces (Chintala et al. 2013; Iida et al. 2013).

Our results did not indicate desorption of $\mathrm{N}$ from biochar during the experiment $(215 \mathrm{~h})$. Again, this was probably
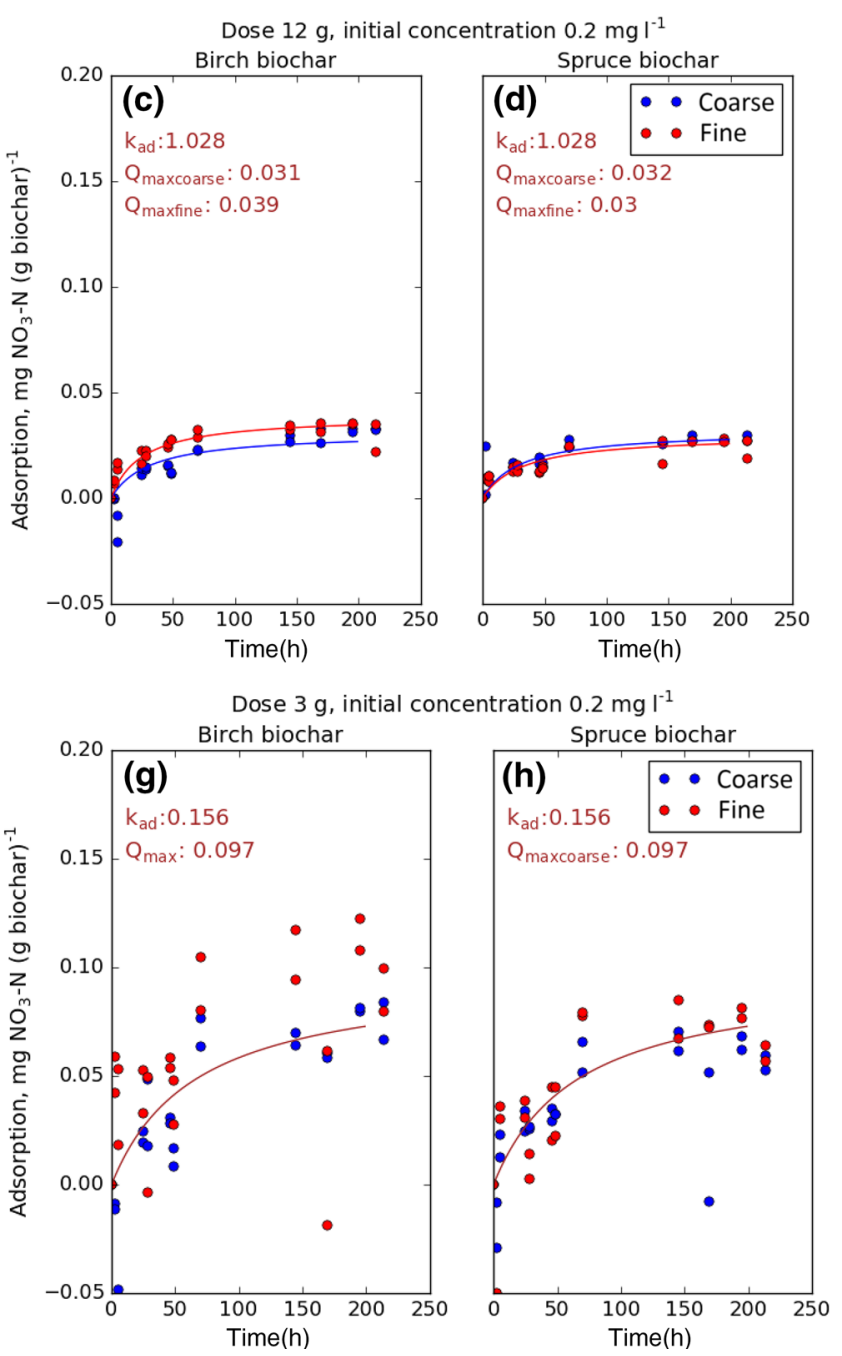

The solid lines represent pseudo-second-order adsorption model (Eq. 2) fitted using non-linear mixed effect model. Parameter values for adsorption rate $\left(K_{\mathrm{ad}}\right)$ and adsorption capacity $\left(Q_{\max }\right)$ are shown in each figure. Blue dots and lines represent coarse particle size (4-6 mm) and red dots and lines represent fine particle size $(<4 \mathrm{~mm})$ (colour figure online)

due to limited availability of $\mathrm{N}$ in the water. Chintala et al. (2013) reported that increases in the initial $\mathrm{NO}_{3}{ }^{-}-\mathrm{N}$ concentrations lead to lower bond energy and more exchangeable ions, which increases desorption of $\mathrm{NO}_{3}{ }^{-} \mathrm{N}$ from biochar to the water.

So far, studies of the removal of organic $\mathrm{C}$ from water using biochar are few. Although it has been found that biochar can remove dissolved organic carbon (DOC) from river water (6.4 $\mathrm{mg} \mathrm{DOC} \mathrm{g}^{-1} \mathrm{C}$; Lee et al. 2018), our results imply that TOC concentrations were increased with biochar addition. This can be due to biochar itself releasing organic $\mathrm{C}$ into water. Different types of biochar contain a range of organic $\mathrm{C}$ and nutrient forms with different release rates 
Table 3 Nonlinear mixed-effect models for $\mathrm{NO}_{3}{ }^{-} \mathrm{N}$ in different treatments

\begin{tabular}{|c|c|c|c|c|c|c|c|c|c|}
\hline & Value & SE & $\mathrm{DF}$ & $p$ value & & Value & SE & DF & $p$ value \\
\hline \multicolumn{5}{|c|}{ Dose $12 \mathrm{~g}$, initial $\mathrm{NO}_{3}{ }^{-}-\mathrm{N}$ concentration $0.6 \mathrm{mg} \mathrm{l}^{-1}$} & \multicolumn{5}{|c|}{ Dose $3 \mathrm{~g}$, initial $\mathrm{NO}_{3}^{-}-\mathrm{N}$ concentration $0.6 \mathrm{mg} \mathrm{l}^{-1}$} \\
\hline$k_{\text {ad }}$ & 0.417 & 0.196 & 76 & 0.037 & $k_{\mathrm{ad}}$ & 0.559 & 0.3 & 108 & 0.065 \\
\hline$Q_{\max }$ birch coarse & 0.068 & 0.008 & 76 & $<0.0001$ & $Q_{\max }$ birch coarse & 0.052 & 0.01 & 108 & $<0.0001$ \\
\hline$Q_{\max }$ spruce & -0.013 & 0.005 & 76 & 0.013 & $Q_{\max }$ spruce & 0.006 & 0.011 & 108 & 0.601 \\
\hline$Q_{\max }$ fine & 0.005 & 0.003 & 108 & 0.088 & $Q_{\max }$ fine & 0.059 & 0.011 & 108 & $<0.0001$ \\
\hline$Q_{\max }$ fine $\times$ spruce & -0.013 & 0.005 & 108 & 0.006 & $Q_{\max }$ fine $\times$ spruce & -0.057 & 0.015 & 108 & 0.0003 \\
\hline \multicolumn{5}{|c|}{ Dose $12 \mathrm{~g}$, initial $\mathrm{NO}_{3}{ }^{-}-\mathrm{N}$ concentration $0.2 \mathrm{mg} \mathrm{l}^{-1}$} & \multicolumn{5}{|c|}{ Dose $3 \mathrm{~g}$, initial $\mathrm{NO}_{3}{ }^{-}-\mathrm{N}$ concentration $0.2 \mathrm{mg} \mathrm{l}^{-1}$} \\
\hline$k_{\text {ad }}$ & 1.028 & 0.29 & 108 & 0.0006 & $k_{\mathrm{ad}}$ & 0.156 & 0.095 & 111 & 0.104 \\
\hline$Q_{\max }$ birch coarse & 0.031 & 0.003 & 108 & $<0.0001$ & $Q_{\max }$ & 0.097 & 0.017 & 111 & $<0.0001$ \\
\hline$Q_{\max }$ spruce & 0.001 & 0.002 & 108 & 0.666 & & & & & \\
\hline$Q_{\text {max }}$ fine & 0.008 & 0.002 & 108 & 0.002 & & & & & \\
\hline$Q_{\max }$ fine $\times$ spruce & -0.011 & 0.003 & 108 & 0.003 & & & & & \\
\hline
\end{tabular}

The uppermost line for $Q_{\max }$ represents the basic level of the adsorption capacity; the other treatment effects and the interaction effects are expressed as a difference with respect to this basic level. Absolute $Q_{\max }$ values are presented in Fig. 5
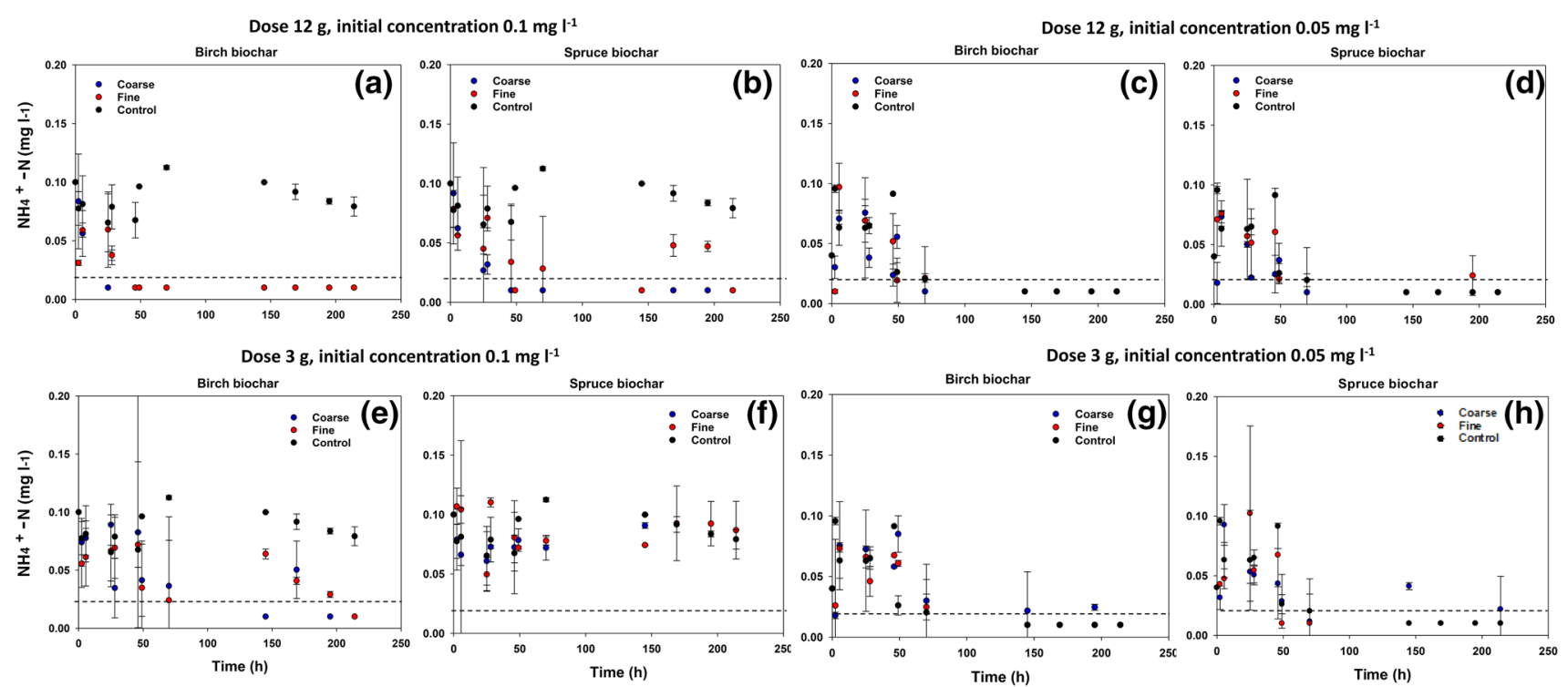

Fig. 6 The effect of biochar on $\mathrm{NH}_{4}^{+}-\mathrm{N}$ concentrations in different treatments: $\mathbf{a} 12 \mathrm{~g}$ of birch biochar and $\mathbf{b} 12 \mathrm{~g}$ of spruce biochar (initial concentration $0.1 \mathrm{mg} \mathrm{l}^{-1}$ ), c $12 \mathrm{~g}$ of birch biochar and $\mathbf{d} 12 \mathrm{~g}$ of spruce biochar (initial concentration $0.05 \mathrm{mg}^{-1}$ ), e $3 \mathrm{~g}$ of birch biochar and $\mathbf{f} 3 \mathrm{~g}$ of spruce biochar (initial concentration $0.1 \mathrm{mg}^{-1}$ ), and

(Mukherjee and Zimmerman 2013), which should be considered in further experiments.

Current water protection methods used in forested peatlands, such as sedimentation ponds, sedimentation pits, overland flow fields and peak-flow control methods, retain suspended solids, but are not capable to effectively remove $\mathrm{NO}_{3}{ }^{-}-\mathrm{N}$ from runoff water (Joensuu et al. 2002; Liljaniemi et al. 2003; Nieminen et al. 2005). Furthermore, riparian buffer zones and overland flow fields require large areas, and nutrient retention through plant uptake is restricted to the growing season (Liljaniemi et al. 2003; Nieminen et al. g $3 \mathrm{~g}$ of birch biochar and $\mathbf{h} 3 \mathrm{~g}$ of spruce biochar (initial concentration $0.05 \mathrm{mg} \mathrm{l}^{-1}$ ). Values are mean $\pm \mathrm{SD}$. Dashed lines represent the detection limit $\left(0.02 \mathrm{mg} \mathrm{l}^{-1}\right)$. Blue dots represent coarse particle size (4-6 mm), red dots represent fine particle size $(<4 \mathrm{~mm})$, and black dots are blank water samples without biochar (colour figure online)

2005). Available physico-chemical and biological technologies developed for $\mathrm{NO}_{3}{ }^{-} \mathrm{N}$ removal in turn tend to be expensive and generate additional by-products and $\mathrm{NO}_{3}{ }^{-} \mathrm{N}$ concentrated waste streams (Bhatnagar and Sillanpää 2011). Our results demonstrating adsorption-based removal of $\mathrm{NO}_{3}{ }^{-}-\mathrm{N}$ thus provide the first evidence on potential solutions to reduce $\mathrm{NO}_{3}{ }^{-}-\mathrm{N}$ leaching from fertile peatlands, where $\mathrm{N}$ exports may significantly increase after the clear-cutting (between 0.05 and $0.22 \mathrm{mg} \mathrm{l}^{-1}$ increase in $\mathrm{NO}_{3}{ }^{-}-\mathrm{N}$; Nieminen 2004). The detected positive relationship between the initial concentration and adsorption capacity also indicates 
that higher nutrient exports would lead to even more efficient adsorption of nutrients, which is ideal for the operability of the biochar reactor in the field conditions. Since the concentration decrease was the most evident during the first 2 days of the experiment, also relatively short water residence time in the biochar reactor can be sufficient for the adsorption of nutrients onto biochar surfaces in the field conditions. On the other hand, the use of biochar reactor might not be beneficial in the field sites with very low inorganic $\mathrm{N}$ concentrations, because the runoff water would probably run out of $\mathrm{NO}_{3}{ }^{-} \mathrm{N}$ and $\mathrm{NH}_{4}{ }^{+}-\mathrm{N}$ during the first week after installation.

As a regenerable adsorbent, biochar could be used as a soil amendment following the adsorption-based water purification. Biochar addition has been found to improve soil properties and the growth of crops and trees (Biederman and Harpole 2013; Lehmann and Joseph 2015; Palviainen et al. 2018), and nutrients adsorbed onto biochar are easily available for plants when placed in the soil (Taghizadeh-Toosi et al. 2012). Therefore, the utilization of biochar as an adsorbent can further improve its potential as a soil amendment.

\section{Conclusions}

Our results indicated efficient adsorption of $\mathrm{N}$ onto biochar surfaces. The highest $Q_{\max }$ was achieved with maximum TN levels, using fine birch biochar. Increases in the export of terrestrial dissolved organic N (DON) to boreal aquatic ecosystems further emphasize the need for effective water protection to which adsorption-based $\mathrm{N}$ removal with biochar seems to respond well. Unlike the traditional water protection methods currently used in forestry, biochar is also capable of adsorbing $\mathrm{NO}_{3}^{-}-\mathrm{N}$ from forest runoff water, which makes biochar a promising tool in development of new water protection methods.

Acknowledgements Open access funding provided by University of Eastern Finland (UEF) including Kuopio University Hospital. This study was funded by Marjatta and Eino Kolli Foundation, the Academy of Finland (funding decisions 311925 and 326818), the Academy of Finland Centre of Excellence (project no. 307331) and Doctoral Programme in Environmental Physics, Health and Biology (University of Eastern Finland). We thank Metsähallitus for providing the study site for our use and Marjut Wallner and Marja Noponen for help in laboratory analyses.

\section{Compliance with ethical standards}

Conflict of interest The authors declare that they have no conflict of interest.

Open Access This article is licensed under a Creative Commons Attribution 4.0 International License, which permits use, sharing, adaptation, distribution and reproduction in any medium or format, as long as you give appropriate credit to the original author(s) and the source, provide a link to the Creative Commons licence, and indicate if changes were made. The images or other third party material in this article are included in the article's Creative Commons licence, unless indicated otherwise in a credit line to the material. If material is not included in the article's Creative Commons licence and your intended use is not permitted by statutory regulation or exceeds the permitted use, you will need to obtain permission directly from the copyright holder. To view a copy of this licence, visit http://creativecommons.org/licenses/by/4.0/.

\section{References}

Ahmadvand M, Soltani J, Hashemi Garmdareh SE, Varavipour M (2018) The relationship between the characteristics of Biochar produced at different temperatures and its impact on the uptake of $\mathrm{NO}_{3}{ }^{-}$-N. Environ Health Eng Manag 5:67-75

Åström M, Aaltonen EK, Koivusaari J (2001) Impact of ditching in a small forested catchment on concentrations of suspended material, organic carbon, hydrogen ions and metals in stream water. Aquat Geochem 7:57-73

Berger C (2012) Biochar and activated carbon filters for greywater treatment-comparison of organic matter and nutrients removal. Thesis no: 2012:14, Swedish University of Agricultural Sciences (SLU), Department of Energy and technology

Bhatnagar A, Sillanpää M (2011) A review of emerging adsorbents for nitrate removal from water. Chem Eng J 168:493-504

Biederman LA, Harpole WS (2013) Biochar and its effects on plant productivity and nutrient cycling: a meta-analysis. GCB Bioenergy 5:202-214

Chintala R, Mollinedo J, Schumacher TE et al (2013) Nitrate sorption and desorption in biochars from fast pyrolysis. Micropor Mesopor Mat 179:250-257

Dalahmeh SS (2016) Capacity of biochar filters for wastewater treatment in onsite systems - technical report. SLU report 2016:090. SLU-Swedish University of Agricultural Sciences, Uppsala (ISBN: 978-91-576-9398-3)

Eberhardt TL, Min SH (2008) Biosorbents prepared from wood particles treated with anionic polymer and iron salt: effect of particle size on phosphate adsorption. Bioresour Technol 99:626-630

Eberhardt TL, Min SH, Han JS (2006) Phosphate removal by refined aspen wood fiber treated with carboxymethyl cellulose and ferrous chloride. Bioresour Technol 97:2371-2376

Fawcett JK, Scott J (1960) A rapid and precise method for the determination of urea. J Clin Pathol 13:156-159

Foereid B (2015) Biochar in nutrient recycling - the effect and its use in wastewater treatment. OJSS 5:39-44

Gwenzi W, Chaukura N, Noubactep C, Mukome FND (2016) Biochar-based water treatment systems as a potential low-cost and sustainable technology for clean water provision. J Environ Manag 197:732-749

Hollister CC, Bisogni JJ, Lehmann J (2013) Ammonium, nitrate, and phosphate sorption to and solute leaching from biochars prepared from corn stover (Zea mays L.) and oak wood (Quercus spp.). J Environ Qual 42:137-144

Iida T, Amano Y, Machida M, Imazeki F (2013) Effect of surface property of activated carbon on adsorption of nitrate ion. Chem Pharm Bull 61:1173

Inyang M, Dickenson E (2015) The potential role of biochar in the removal of organic and microbiological contaminants from potable and reuse water: a review. Chemosphere 134:232-240

Joensuu S, Ahti E, Vuollekoski M (2002) Effects of ditch network maintenance on the chemistry of run-off water from peatland forests. Scand J For Res 17:238-247

Kameyama K, Miyamoto T, Iwata Y, Shiono T (2016) Influences of feedstock and pyrolysis temperature on the nitrate adsorption of biochar. J Soil Sci 62:180-184 
Kizito S, SB W, Kirui WK, Lei M, QM L, Bah H, Dong RJ (2015) Evaluation of slow pyrolyzed wood and rice husks biochar for adsorption of ammonium nitrogen from piggery manure anaerobic digestate slurry. Sci Total Environ 505:102-112

Krishnan KA, Haridas A (2008) Removal of phosphate from aqueous solutions and sewage using natural and surface modified coir pith. J Hazard Mater 152:527-535

Lafdani EK, Saarela T, Laurén A, Pumpanen J, Palviainen M (2020) Purification of forest clear-cut runoff water using biochar: a meso-scale laboratory column experiment. Water 12:478

Largitte L, Pasquier R (2016) A review of the kinetics adsorption models and their application to the adsorption of lead by an activated carbon. Chem Eng Res Des 109:495-504

Lee DJ, Cheng YL, Wong RJ, Wang XD (2018) Adsorption removal of natural organic matters in waters using biochar. Biores Technol 260:413-416

Lehmann J, Joseph S (eds) (2015) Biochar for environmental management: science, technology and implementation. Routledge, London, p 944

Liljaniemi P, Vuori KM, Tossavainen T, Kotanen J, Haapanen M, Lepistö A, Kenttämies K (2003) Effectiveness of constructed overland flow areas in decreasing diffuse pollution from forest drainages. Environ Manag 32:602-613

Miranda KM, Espey MG, Wink DA (2001) A rapid, simple spectrophotometric method for simultaneous detection of nitrate and nitrite. Nitric Oxide 5:62-71

Mizuta K, Matsumoto T, Hatate Y, Nishihara K, Nakanishi T (2004) Removal of nitrate-nitrogen from drinking water using bamboo powder charcoal. Biores Technol 95:255-257

Mohan D, Sarswat A, Ok YS, Pittman CU (2014) Organic and inorganic contaminants removal from water with biochar, a renewable, low cost and sustainable adsorbent-a critical review. Bioresour Technol 160:191-202

Mukherjee A, Zimmerman AR (2013) Organic carbon and nutrient release from a range of laboratory-produced biochars and biochar-soil mixtures. Geoderma 193:122-130

Nieminen M (2004) Export of dissolved organic carbon, nitrogen and phosphorus following clear-cutting of three norway spruce forests growing on drained peatlands in Southern Finland. Silva Fenn 38:123-132

Nieminen M, Ahti E, Nousiainen H, Joensuu S, Vuollekoski M (2005) Does the use of riparian buffer zones in forest drainage sites to reduce the transport of solids simultaneously increase the export of solutes? Boreal Environ Res 10:191-201

Nieminen M, Palviainen M, Sarkkola S, Laurén A, Marttila H, Finér L (2017a) A synthesis of the impacts of ditch network maintenance on the quantity and quality of runoff from drained boreal peatland forests. Ambio 47:523-534

Nieminen M, Sallantaus T, Ukonmaanaho L, Nieminen T, Sarkkola S (2017b) Nitrogen and phosphorus concentrations in discharge from drained peatland forests are increasing. Sci Total Environ 609:974-981
Novak JM, Busscher WJ, Watts DW, Laird DA, Ahmedna MA, Niandou MAS (2010) Short-term $\mathrm{CO}_{2}$ mineralization after additions of biochar and switchgrass to a Typic Kandiudult. Geoderma 154:281-288

Oliveira RF, Patel AK, Jaisi DP, Adhikari S, Lu H, Khanal SK (2018) Environmental application of biochar: current status and perspectives. Bioresour Technol 246:110-122

Päivänen J, Hånell B (2012) Peatland ecology and forestry—a sound approach. University of Helsinki, Department of Forest Sciences Publications: 2012. Helsinki, Finland p 267

Palviainen M, Berninger F, Bruckman VJ, Köster K, de Assumpção CRM, Aaltonen H, Zhou X (2018) Effects of biochar on carbon and nitrogen fluxes in boreal forest soil. Plant Soil 425:71-85

Pirinen P, Simola H, Aalto J, Kaukoranta JP, Karlsson P, Ruuhela R (2012) Climatological statistics of Finland 1981-2010. Reports 2012:1. Finnish Meteorological Institute, p 96

Sarkhot DV, Ghezzehei TA, Berhe AA (2013) Effectiveness of biochar for sorption of ammonium and phosphate from dairy effluent. J Environ Qual 42:1545-1554

Sha Z, Li Q, Lv T, Misselbrook T, Liu X (2019) Response of ammonia volatilization to biochar addition: a meta-analysis. Sci Tot Env 655:1387-1396

Taghizadeh-Toosi A, Clough TJ, Sherlock RR, Condron LM (2012) Biochar adsorbed ammonia is bioavailable. Plant Soil 350:57-69

Takaya CA, Fletcher LA, Singh S, Anyikude KU, Ross AB (2016) Phosphate and ammonium sorption capacity of biochar and hydrochar from different wastes. Chemosphere 145:518-527

Tan X, Liu Y, Zeng G, Wang X, Hua X, Gu Y, Yang Z (2015) Application of biochar for the removal of pollutants from aqueous solutions. Chemosphere 125:70-85

Wang ZH, Guo HY, Shen F, Yang G, Zhang YZ, Zeng YM, Wang LL, Xiao H, Deng SH (2015) Biochar produced from oak sawdust by lanthanum (La)-involved pyrolysis for adsorption of ammonium $\left(\mathrm{NH}_{4}^{+}\right)$, nitrate $\left(\mathrm{NO}_{3}^{-}\right)$, and phosphate $\left(\mathrm{PO}_{3}^{-4}\right)$. Chemosphere 119:646-653

Yao Y, Gao B, Inyang M, Zimmerman AR, Cao XD, Pullammanappallil P, Yang LY (2011) Removal of phosphate from aqueous solution by biochar derived from anaerobically digested sugar beet tailings. J Hazard Mater 190:501-507

Yao Y, Gao B, Zhang M, Inyang M, Zimmerman AR (2012) Effect of biochar amendment on sorption and leaching of nitrate, ammonium, and phosphate in a sandy soil. Chemosphere 89:1467-1471

Yin Q, Zhang B, Wang R, Zhao Z (2017) Biochar as an adsorbent for inorganic nitrogen and phosphorus removal from water: a review. Environ Sci Pollut Res 24:26297-26309

Zhang M, Gao B, Yao Y, Xue YW, Inyang M (2012) Synthesis of porous $\mathrm{MgO}$-biochar nanocomposites for removal of phosphate and nitrate from aqueous solutions. Chem Eng J 210:26-32

Zhang Y, Li ZF, Mahmood IB (2014) Recovery of $\mathrm{NH}_{4}{ }^{+}$by corn cob produced biochars and its potential application as soil conditioner. Front Environ Sci Eng 8:825-834 